\title{
Comparison of the Short-Term Effect of Steroid Dosage Regimens in Patients with Idiopathic Sudden Sensorineural Hearing Loss
}

\author{
Gi Yun Nam, Jae Beom Ko, Hwan Ho Lee, and Jae Hwan Kwon \\ Department of Otolaryngology-Head and Neck Surgery, Kosin University College of Medicine, Busan, Korea
}

\section{돌발성 난청 환자에서 전신 스테로이드 투여 용법에 따른 단기 치료 효과 비교}

남기윤 · 고재범 · 이환호 · 권재환

고신대학교 의과대학 이비인후과학교실

Received July 5, 2016

Revised November 20,2016

Accepted November 28, 2016

Address for correspondence

Jae Hwan Kwon, MD, PhD

Department of Otolaryngology-

Head and Neck Surgery,

Kosin University

College of Medicine,

262 Gamcheon-ro, Seo-gu,

Busan 49267, Korea

Tel $+82-51-990-6470$

Fax $+82-51-245-8539$

E-mail entkwon@hanmail.net
Background and Objectives For idiopathic sudden sensorineural hearing loss (ISSHL) patients, steroids are one of the most important therapies which are used to reduce inflammation in the inner ear. However, dosage regimens of oral steroid therapy have not been well established. This study aims to investigate the progression in recovery from ISSHL, and the optimal dosage regimen with steroids.

Subjects and Method We undertook a retrospective study of 149 patients diagnosed with ISSHL at our institution. We compared various clinical parameters such as age, gender, vertigo, tinnitus, the interval between disease onset and initial treatment, and severity of hearing loss. The 149 patients were divided based on their steroid regimens into two groups: group 1 (which received $40 \mathrm{mg}$ of prednisolone in the morning and $20 \mathrm{mg}$ at night) and group 2 (which received $20 \mathrm{mg}$ of prednisolone three times daily). We then compared the results of group 1 with that of group 2.

Results Recovery rates in group $1(58 / 90,64.4 \%)$ were significantly higher in ISSHL than those in group $2(27 / 59,45.8 \%)$. In particular, the complete recovery rates of Siegel's criteria in group $1(35 / 90,38.9 \%)$ were higher than those in group $2(12 / 59,20.3 \%)$. Therapeutic results were affected by the presence of tinnitus. Of the patients with tinnitus, $64.3 \%$ in group 1 , and $43.9 \%$ in group 2 recovered.

Conclusion In the group treated with twice-daily regimens, greater hearing improvements were observed compared with the group treated with three times-daily regimens. These findings suggest that higher dose for a single administration may be an important prognostic factor. Korean J Otorhinolaryngol-Head Neck Surg 2017;60(2):63-8

Key Words Administration \& dosage $\cdot$ Steroid $\cdot$ Sudden deafness.

\section{서 론}

돌발성 난청은 원인이 명확하지 않으면서 갑작스럽게 발생 하는 감각신경성 난청으로 순음청력검사에서 3개 이상의 연 속된 주파수에서 $30 \mathrm{~dB}$ 이상의 감각신경성 청력 손실이 3일 이내에 발생한 경우로 정의된다. ${ }^{1)}$ 1944년 De Kleyn²)이 처음 보고한 이래 그 원인으로 내이의 순환장애설과 바이러스 감염
설, 청신경 종양, 이독성 약물, 외상, 자가면역성 질환, 선천성 기형 등이 제시되고 있지만 현재까지 정확한 원인 및 발생기 전이 밝혀져 있지 않으며 치료시작 시기, 나이, 어지럼증 및 이 명의 동반 유무, 청력도 유형, 발병 초기 청력소실의 정도 등과 같은 여러 인자들이 치료 반응 및 예후에 영향을 주는 것으로 알려져 있다. ${ }^{3,4}$

돌발성 난청의 치료법으로 혈관 확장제, 고압산소 요법, 항 
바이러스제, 항응고제 등 다양한 방법들이 소개되고 있다. 그 중 스테로이드는 청력회복에 효과가 인정되어 전 세계적인 표 준 치료법으로 널리 쓰이고 있으며 일반적으로 경구 복용으 로 사용하거나 다른 치료법과 병행하여 사용한다. 내이에서 스 테로이드의 작용기전은 명확히 밝혀지지 않았지만 면역반응 의 감소와 와우 내 미세혈류를 증가시킨다고 추정되며 고농 도의 스테로이드일수록 염증반응과 면역세포 생성을 더 억 제시켜 청력의 더 빠른 회복을 돕는다는 보고도 있다. ${ }^{5,6)}$ 하지 만 전신 고용량 스테로이드 치료는 골다공증, 간기능 장애, 녹내장과 같은 심각한 합병증을 유발할 수 있어 투여 용량 및 용법을 선택할 때 어려움이 따른다. ${ }^{7)}$

스테로이드 용량에 따른 효과에 대하여 여러 가지 연구들이 진행되었으며 prednisone $200 \mathrm{mg}$ 을 사용한 군이 prednisone $60 \mathrm{mg}$ 을 사용한 군보다 예후가 좋다는 연구가 있는 반면, ${ }^{8}$ prednisolone $30 \mathrm{mg}$ 이상 사용하는 경우 오히려 예후가 나쁘 다는 연구, ${ }^{9}$ hydrocortisone $800 \mathrm{mg}$ 을 투여한 군과 prednisone $50 \mathrm{mg}$ 을 투여한 군 간에 예후 차이가 없다는 연구도 있다. ${ }^{10)}$ 이처럼 용량의 기준에 대해서는 여전히 논란이 많은 실정이지만 여러 연구들이 진행되어 왔다. 하지만 스테로이드 용법에 따른 치료 효과에 대해서는 현재까지 보고된 바 없다.

따라서 본 연구에서는 돌발성 난청 환자를 용법에 차이에 따라 prednisolone $60 \mathrm{mg}$ 을 오전 $40 \mathrm{mg}$, 저녁 $20 \mathrm{mg}$ 으로 2 회 분복 경구 투여한 1 군과 prednisolone $60 \mathrm{mg}$ 을 오전 20 $\mathrm{mg}$, 오후 $20 \mathrm{mg}$, 저녁 $20 \mathrm{mg}$ 으로 3회 분복 경구 투여한 2군 으로 나누어, 이 두 군에서 치료 1 개월 후의 단기 청력 개선의 효과에 대해 알아보고자 한다.

\section{대상 및 방법}

\section{대 상}

2009년 1월부터 2014년 8월까지 본원 이비인후과에서 돌발 성 난청으로 진단받고 입원치료를 받은 202명의 환자들의 의 무기록을 후향적으로 분석하였다. 돌발성 난청의 선정 기준 은 뚜렷한 원인 없이 순음청력검사상 3 일 이내에 3 개의 연속 되는 주파수에서 $30 \mathrm{~dB}$ 이상의 감각신경성 난청 소견을 보이 는 환자로 하였다. 이 중 전음성 난청이 $10 \mathrm{~dB}$ 이상인 환자, 외 상이나 뇌병변에 의한 난청 환자, 변동성의 난청 환자, 당뇨, 심혈관 질환이 있는 환자는 분석 대상에서 제외하였으며 최 종적으로 149 명의 환자를 대상으로 연구를 진행하였다.

\section{방 법}

연구 대상 환자를 스테로이드의 치료 용법에 따라 prednisolone(Solondo ${ }^{\circledR}$; Yuhan Medica, Seoul, Korea) 60 mg을 오
전 $40 \mathrm{mg}$, 저녁 $20 \mathrm{mg}$ 으로 2회 분복 경구 투여한 1군과 prednisolone $60 \mathrm{mg}$ 을 오전 $20 \mathrm{mg}$, 오후 $20 \mathrm{mg}$, 저녁 $20 \mathrm{mg}$ 으 로 3 회 분복 경구 투여한 2 군으로 나누었다. 1군 스테로이드 요법을 받은 환자는 90 명이었고 2군 스테로이드 요법을 받은 환자는 59 명이었다. 1 군은 1 일에서 5 일까지 $60 \mathrm{mg}$ 를 투여하 고, 이후 2일에 걸쳐 prednisolone $30 \mathrm{mg}$ 을 오전 $20 \mathrm{mg}$, 저녁 $10 \mathrm{mg}$ 으로 감량하였으며, 2군은 1일에서 5일까지 $60 \mathrm{mg}$ 를 투 여 후 2일에 걸쳐 prednisolone $30 \mathrm{mg}$ 을 오전 $10 \mathrm{mg}$, 오후 10 $\mathrm{mg}$, 저녁 $10 \mathrm{mg}$ 으로 감량하였다.

모든 환자는 7일간 입원하여 절대 안정하였으며 동일한 혈 관 확장제 alprostadil(Alostin ${ }^{\circledR}$; Dongkook Medica, Seoul, Korea), 항바이러스제 famciclovir(Famvir ${ }^{\circledR}$; Novartis, Basel, Switzerland)를 투여하였으며 고실 내 스테로이드 주입술을 시행하였다. 고실 내 스테로이드 주입은 입원기간 중 격일로 3 회 시행하였으며 앙와위에서 고개를 시술 반대 측으로 돌린 상태에서 dexamethasone(Dexamethasone phosphate diso$\operatorname{dium}^{\circledR}, 5 \mathrm{mg} / \mathrm{mL}$; Huons Medica, Seoul, Korea)을 $0.3 \mathrm{cc}$ 가 량 주입하고, 이관을 통해 배출되지 않도록 약을 삼키지 않 도록 한 채로 30 분 정도 유지시켰다. 환자들은 양 군 모두 퇴 원 후 추가 스테로이드 처방은 없었으며 혈액순환제 choline alfoscerate(Gliatilin $^{\circledR}$; Daewoong Medica, Seoul, Korea)를 처방하였다.

치료 예후 인자를 어지럼의 유무, 이명, 청력소실 정도로 설 정하여 의무기록을 토대로 후향적 분석을 하였다. 어지럼은 안진 여부 상관 없이 주관적 회전성 어지럼으로 정의하였다.

난청의 정도는 경도(mild, 26 40 dB), 중등도(moderate, 41 $55 \mathrm{~dB}$ ), 중등고도(moderate-severe, 56 70 dB), 고도(severe, 71 90 dB) 그리고 농(profound, $91 \mathrm{~dB}$ 이상)으로 분류하였 다. 순음청력검사는 입원 당시 1 회, 입원기간 중 격일로 3 회, 퇴원 한 달 후 1 회 시행하였으며, 치료 효과는 입원 당시와 퇴 원 후 1 개월에 측정한 순음청력검사를 통해 비교하였다. 평균 청력역치는 500, 1000, 2000, $4000 \mathrm{~Hz}$ 의 6분법으로 계산하 였으며 치료 전 순음청력역치값에서 치료 1 개월 후 순음청력 역치값을 뺀 청력역치호전도와 Siegel's criteria ${ }^{11}$ 를 이용하여 치료 호전 여부를 판정하였다(Table 1). Siegel's criteria의 완

Table 1. The Siegel's criteria of hearing recovery

\begin{tabular}{ll}
\hline \multicolumn{1}{c}{ Type } & \multicolumn{1}{c}{ Hearing recovery } \\
\hline $\begin{array}{l}\text { Complete recovery } \\
\text { Partial recovery }\end{array}$ & $\begin{array}{c}\text { More than } 15 \mathrm{~dB} \text { of gain, final hearing } \\
25-45 \mathrm{~dB}\end{array}$ \\
Slight improvement & $\begin{array}{c}\text { More than } 15 \mathrm{~dB} \text { of gain, final hearing } \\
\text { poorer than } 45 \mathrm{~dB}\end{array}$ \\
No improvement & $\begin{array}{c}\text { Less than } 15 \mathrm{~dB} \text { of gain or final hearing } \\
\text { poorer than } 75 \mathrm{~dB}\end{array}$ \\
\hline
\end{tabular}


전회복군(complete recovery), 부분회복군(partial recovery), 경도회복군(slight improvement)를 청력회복으로 분류 하였을 때 두 군 간의 차이가 있는지, 동반 증상에 따른 두 군 간의 회복률에 차이가 있는지를 비교하였다.

통계적 분석은 SPSS 22.0(IBM Corp., Armonk, NY, USA) 을 이용하여 chi-square test, 데이터가 정규성을 가지지 못한 경우 비모수 검정인 Mann-Whitney U test를 시행하여 두 군 을 비교하였다. $p$ 값이 0.05 이하인 경우에 의미가 있는 것으로 판정하였다. 각 자료의 평균은 중앙값 및 표준편차의 형태로 표기하였다.

\section{결 과}

1 군에서는 평균 나이 $50.7 \pm 18.0$ 세, 남녀비가 54 대 36 이었고 어지럼이 있는 경우는 26 명(28.9\%), 이명이 있는 경우는 56명 (62.2\%), 어지럼과 이명이 동반된 경우는 20명(22.2\%)이었다. 발병 후 초기 치료가 이루어지기까지의 기간은 평균 $11.3 \pm$ 18.5 일이었으며 난청 정도는 경도 26 명(28.9\%), 중등도 18 명 (20.0\%), 중등고도 20명(22.2\%), 고도 17명(18.9\%), 농 9명 (10.0\%)의 분포를 나타내었다. 각 주파수별 순음청력역치의 평균은 $0.5 \mathrm{kHz}$ 에서 $57.7 \pm 25.8 \mathrm{~dB}, 1 \mathrm{kHz}$ 에서 $59.3 \pm 26.1 \mathrm{~dB}$, $2 \mathrm{kHz}$ 에서 $58.2 \pm 26.8 \mathrm{~dB}, 4 \mathrm{kHz}$ 에서 $61.6 \pm 26.8 \mathrm{~dB}$ 의 수치 를 보였다.

2군에서는 평균 나이 $48.6 \pm 16.6$ 세, 남녀비가 29대 30이었
고 어지럼이 있는 경우는 18명(30.5\%), 이명이 있는 경우는 41 명 (69.5\%), 어지럼과 이명이 동반된 경우는 12명(20.3\%)이었다. 발병 후 초기 치료가 이루어지기까지의 기간은 평균 $6.2 \pm 6.9$ 일이었으며 난청 정도는 경도 10 명(16.9\%), 중등도 16 명(27.1\%), 중등고도 15 명(25.4\%), 고도 12명(20.3\%), 농 6명(10.2\%)의 분 포를 나타내었다. 각 주파수별 순음청력역치의 평균은 0.5 $\mathrm{kHz}$ 에서 $61.9 \pm 27.0 \mathrm{~dB}, 1 \mathrm{kHz}$ 에서 $63.4 \pm 25.5 \mathrm{~dB}, 2 \mathrm{kHz}$ 에 서 $61.5 \pm 25.2 \mathrm{~dB}, 4 \mathrm{kHz}$ 에서 $70.5 \pm 28.5 \mathrm{~dB}$ 의 수치를 보였 다(Table 2). 양 군을 비교하였을 때 연령, 성별, 어지럼, 이명, 어지럼과 이명의 동반, 발병 후 초기 치료까지의 기간, 난청 정 도, 주파수별 순음청력역치 평균값의 통계학적 차이는 없었다. 청력역치호전도는 $0.5 \mathrm{kHz}$ 에서 1군은 $23.9 \pm 22.4 \mathrm{~dB}, 2$ 군 은 $18.8 \pm 24.0 \mathrm{~dB}$ 로 나타났으며 $(p=0.246), 1 \mathrm{kHz}$ 에서 1군은 $23.3 \pm 21.7 \mathrm{~dB}, 2$ 군은 $19.3 \pm 21.5 \mathrm{~dB}(p=0.566), 2 \mathrm{kHz}$ 에서 1 군은 $19.3 \pm 19.9 \mathrm{~dB}, 2$ 군은 $17.3 \pm 20.9 \mathrm{~dB}$ 이 나타났다( $p=0.709)$. $4 \mathrm{kHz}$ 에서 1군은 $12.2 \pm 17.3 \mathrm{~dB}, 2$ 군은 $13.2 \pm 19.3 \mathrm{~dB}$ 이 나타 났다 $(p=0.695)$. 6 분법으로 측정한 순음청력검사상 1 군은 평 균 $20.1 \pm 18.9 \mathrm{~dB}, 2$ 군은 평균 $16.2 \pm 20.0 \mathrm{~dB}$ 이 나타났다 $(p=$ 0.408). $0.5 \mathrm{kHz}, 1 \mathrm{kHz}, 2 \mathrm{kHz}, 4 \mathrm{kHz}, 6$ 분법 평균 모두 양 군에 통계학적 차이는 없었다(Fig. 1). Siegels criteria에 따 라 청력회복을 분류하였을 때, 완전회복군은 1 군에서 35 명 (38.9\%), 2군에서 12명(20.3\%)이었으며 양 군이 통계적으로 유의한 차이를 보여 $(p=0.020), 1$ 군에서 청력의 완전회복이 더 우월한 것을 확인할 수 있었다. 완전회복군과 부분회복군을

Table 2. Baseline demographic and clinical characteristics of patients according to treatment method

\begin{tabular}{|c|c|c|c|}
\hline & Group 1* $(n=90)$ & Group $2^{+}(n=59)$ & $p$-value \\
\hline Mean age (years) & $50.7 \pm 18.0$ & $48.6 \pm 16.6$ & 0.470 \\
\hline$M: F$ & $54: 36$ & $29: 30$ & 0.192 \\
\hline Vertigo (\%) & $26(28.9)$ & $18(30.5)$ & 0.832 \\
\hline Tinnitus (\%) & $56(62.2)$ & $41(69.5)$ & 0.363 \\
\hline Vertigo+tinnitus (\%) & $20(22.2)$ & $12(20.3)$ & 0.784 \\
\hline Duration from onset (days) & $11.3 \pm 18.5$ & $6.2 \pm 6.9$ & 0.447 \\
\hline \multicolumn{4}{|l|}{ Severity of hearing loss (\%) } \\
\hline Mild & $26(28.9)$ & $10(16.9)$ & 0.543 \\
\hline Moderate & $18(20.0)$ & $16(27.1)$ & \\
\hline Moderate-severe & $20(22.2)$ & $15(25.4)$ & \\
\hline Severe & $17(18.9)$ & $12(20.3)$ & \\
\hline Profound & $9(10.0)$ & $6(10.2)$ & \\
\hline \multicolumn{4}{|c|}{ Hearing level in each frequency $(\mathrm{dB})$} \\
\hline $0.5 \mathrm{kHz}$ & $57.7 \pm 25.8$ & $61.9 \pm 27.0$ & 0.333 \\
\hline $1 \mathrm{kHz}$ & $59.3 \pm 26.1$ & $63.4 \pm 25.5$ & 0.334 \\
\hline $2 \mathrm{kHz}$ & $58.2 \pm 26.8$ & $61.5 \pm 25.2$ & 0.453 \\
\hline $4 \mathrm{kHz}$ & $61.6 \pm 26.8$ & $70.5 \pm 28.5$ & 0.052 \\
\hline PTA $\ddagger(d B)$ & $58.6 \pm 23.9$ & $63.3 \pm 23.7$ & 0.241 \\
\hline
\end{tabular}

*received $40 \mathrm{mg}$ of prednisolone in the morning and $20 \mathrm{mg}$ at night, treceived $20 \mathrm{mg}$ of prednisolone three times daily, $\neq$ average of the thresholds at $0.5,1,2$ and $4 \mathrm{kHz}$. PTA: pure tone average 


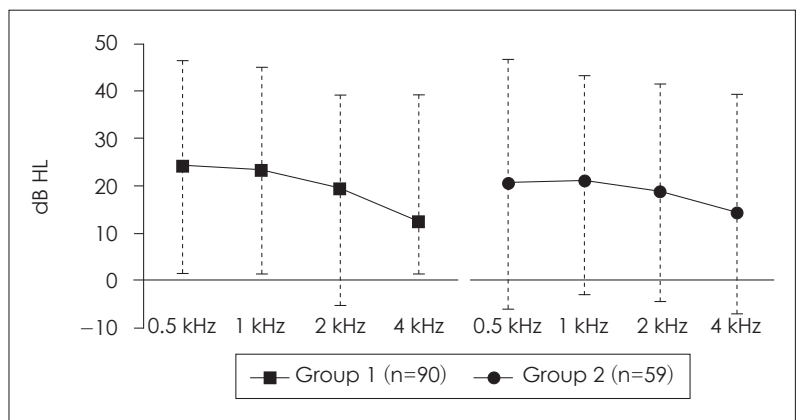

Fig. 1. Hearing improvement between two groups, which is the difference of the result of pure tone average before and after the treatment.

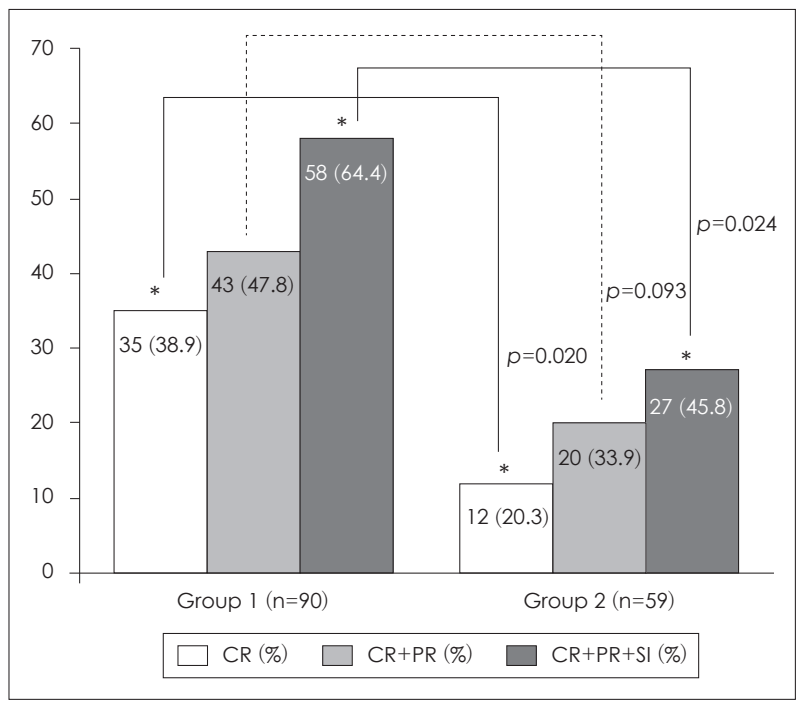

Fig. 2. Recovery rate according to treatment modality on Siegel's criteria. ${ }^{*} p<0.05$. CR: complete recovery, PR: partial recovery, SI: slight improvement.

합하였을 때 1군에서는 43명(47.8\%), 2군에서는 20명(33.9\%)을 보였으며 통계학적인 차이는 없었다 $(p=0.093)$. 완전회복군, 부분회복군, 경도회복군을 청력회복이 있다고 가정하였을 때, 1군은 58명(64.4\%)에서 청력회복을 보였고, 2군은 27명 (45.8\%)에서 청력회복을 보였으며 통계학적으로 유의한 차이 를 보여 $(p=0.024), 1$ 군이 청력회복이 더 우월한 것을 확인할 수 있었다(Fig. 2).

동반된 증상에 따른 양 군의 회복률 차이를 비교해 보았을 때, 어지럼이 동반된 경우 1 군에서 $50.0 \%$ 의 회복률을 보였고 2군에서는 $27.8 \%$ 의 회복률을 보였으나 통계학적으로 유의 한 차이는 없었다 $(p=0.140)$. 이명이 동반된 경우 1 군은 $64.3 \%$, 2군에서는 $43.9 \%$ 의 회복률을 보여 통계학적으로 유의한 차 이를 보여 1군이 청력회복이 더 우월한 것을 확인할 수 있었 다 $(p=0.046)$. 어지럼과 이명이 같이 동반된 경우 1 군은 $45.0 \%$, 2 군은 $25.0 \%$ 의 회복률을 보였으며 통계학적으로 유의한 차 이는 없었다 $(p=0.258)$. 치료 전 난청 정도에 따른 회복률은 경
Table 3. Recovery rate according to treatment method, accompanying symptoms, severity of initial hearing loss

\begin{tabular}{lrrr}
\hline & \multicolumn{3}{c}{ Recovery* rate (\%) } \\
\cline { 2 - 4 } & Group 1 & Group 2 & p-value \\
\hline Accompanying symptom & & & \\
$\quad$ Vertigo & $13 / 26(50.0)$ & $5 / 18(27.8)$ & 0.140 \\
Tinnitus & $36 / 56(64.3)$ & $18 / 41(43.9)$ & $0.046^{\dagger}$ \\
$\quad$ Vertigo+tinnitus & $9 / 20(45.0)$ & $3 / 12(25.0)$ & 0.258 \\
Initial hearing & & & \\
Mild & $19 / 26(73.1)$ & $6 / 10(60.0)$ & 0.446 \\
Moderate & $9 / 18(50.0)$ & $4 / 16(25.0)$ & 0.134 \\
Moderate-severe & $10 / 20(50.0)$ & $9 / 15(60.0)$ & 0.557 \\
Severe & $14 / 17(82.4)$ & $7 / 12(58.3)$ & 0.218 \\
Profound & $6 / 9(66.7)$ & $1 / 6(16.7)$ & 0.119 \\
\hline
\end{tabular}

*complete recovery+partial recovery+slight improvement, ${ }^{\dagger} \mathrm{chi}-$ square test

도 난청 시 1군은 $73.1 \%, 2$ 군은 $60.0 \%$ 를 중등도 난청 시 1군 은 50.0\%, 2군은 $25.0 \%$ 를 중등고도 난청에서 1군은 $50.0 \%$, 2군은 $60.0 \%$ 를 고도 난청에서 1군은 $82.4 \%, 2$ 군은 $58.3 \%$ 를 농에서 1 군은 $66.7 \%, 2$ 군은 $16.7 \%$ 가 회복되었으나 난청 정도 에 따른 양 군 간의 청력회복률의 통계학적인 유의한 차이는 없었다(Table 3).

\section{고 찰}

돌발성 난청은 이과적 응급질환으로 수 시간 내지 수일 동 안에 걸쳐 돌발적으로 발생하는 원인 불명의 감각신경성 난 청을 말한다. 현재까지 많은 연구들이 이루어졌으나 아직 병 인이나 치료 방법이 명확히 밝혀지지 않았으며 그중 바이러 스 감염, 혈관장애, 내이막 파열 등이 주된 발병 기전으로 생 각된다. ${ }^{12)}$ 병인이 다양하므로 스테로이드, 항바이러스제, 이뇨 제, 혈관 확장제 등 주로 항염증작용 및 혈류 개선을 목적으 로 하는 치료법이 주로 이용되고 있으며 그중 Wilson 등흐는 전향적 연구를 통해 특히 중고도 이상의 난청에서 스테로이 드가 가장 효과적인 치료제임을 증명하였다. 스테로이드는 체 내에 흡수되면 glucocorticoid 수용체와 결합하여 염증반응 유발과 면역세포 생성에 관여하는 전사인자(transcription factor)인 NF- $\kappa \beta$ (nuclear factor-kappa beta)의 활성을 억제시 키고, 또한 mineralocorticoid 수용체와 결합하여 와우관 내 혈관조, 나선인대 등에 존재하는 $\mathrm{Na}^{+}, \mathrm{K}^{+}$-ATPase를 활성화 시켜 내림프액의 항상성을 조절한다. ${ }^{14-16)}$ 스테로이드의 사용 량과 기간에는 다양한 프로토콜이 있으나 아직 정확한 투여 방법에 대해서는 여전히 정립된 바가 없다. 특히 돌발성 난청 환자에서 전신적 스테로이드 투여 용법에 관한 비교연구는 없 는 실정이며 현재 prednisone $60 \mathrm{mg} / \mathrm{day}$ 를 7 14일에 걸쳐 투 
여하는 방법이 흔히 사용되고 있다. ${ }^{17)}$

본 연구에서는 투여 용법에 따른 치료 효과를 분석하였을 때, 1군에서 Siegel's criteria에 따른 호전율(recovery rate)과 완전 회복률이 더 우월한 것을 확인할 수 있었는데, 이는 스 테로이드의 투여량과 내이의 $\mathrm{Na}^{+}, \mathrm{K}^{+}-\mathrm{ATPase}$ 의 활성도는 밀접한 연관성이 있어 투여 농도가 높을수록 염증반응과 면 역세포 생성을 더 억제시켜 청력회복률이 높고 청력회복이 더 빨리 이루어진다는 연구결과에 비춰볼 때 1 군에서 청력회 복률이 더 높은 이유를 추정해 볼 수 있다. ${ }^{6,18)}$

돌발성 난청의 예후와 관계되는 인자로는 환자의 나이, 치 료시작 시기, 어지럼의 동반 유무, 초기 청력소실의 정도 등이 보고되고 있다. ${ }^{19,20)}$ 어지럼이 동반된 돌발성 난청의 경우 동 반된 경우가 동반되지 않은 군에서보다 예후가 나쁘다고 $\mathrm{Byl},{ }^{19)} \mathrm{Sheehy}^{21)}$ 등의 연구를 통해 알려져 있으나 뚜렷한 차 이가 없다는 보고도 있어 ${ }^{22)}$ 논란의 여지가 있다. 본 연구에서 는 어지럼이 있는 환자군에서 1 군과 2 군의 청력회복률에 차 이가 있는지 비교하였으나 통계학적으로 유의한 차이가 없 음을 알 수 있었다. Cvorović 등 ${ }^{23)}$ 과 Ben-David 등 ${ }^{24)}$ 의 연구 에 따르면 이명이 동반된 경우, 동반되지 않은 군에 비해 예후 가 양호하다고 하였으나 Chang 등 ${ }^{25)}$ 은 이명과 예후와는 무관 하다고 보고하였다. 본 연구에 따르면 1군에서 $64.3 \%, 2$ 군에 서 $43.9 \%$ 의 청력호전율을 보여 1군에서 청력회복이 더 우월 함을 확인하였으며 통계학적으로 의미 있는 차이가 있었다. 어지럼과 이명이 같이 동반된 경우 모두 두 군에서 통계학적 으로 유의한 차이는 없었다.

치료 전 청력소실의 정도와 예후에 대한 이전의 연구에 따 르면 Sheehy ${ }^{21)}$ 는 500 $2000 \mathrm{~Hz}$ 의 평균 청력 손실이 $45 \mathrm{~dB}$ 이 내는 예후가 양호하다고 하였고, $\mathrm{Byl}^{19)}$ 은 초기 청력소실이 클 수록 예후는 불량한 것으로 보고하였다. 하지만 본 연구에서 는 두 군 모두 치료 전 청력소실이 클수록 회복률이 떨어지 는 소견을 확인할 수 없었으며 통계학적으로도 두 군 간의 유 의한 차이를 보이지 않았다.

청력호전을 평가하는 기준에는 다양한 방법들이 존재한 다. Wilson 등 ${ }^{13)}$ 은 최초청력에서 $50 \%$ 이상의 호전을 보였을 때 성공으로 보았으며 Mattox와 Simmons ${ }^{26}$ 는 $40 \mathrm{~dB}$ 이하의 순음청력역치를 보이거나 $50 \mathrm{~dB}$ 이상의 호전을 보이는 경우를 성공으로 정의하였다. Gianoli와 $\mathrm{Li}^{27)}$ 는 순음청력검사 또는 speech reception threshold에서 $10 \mathrm{~dB}$ 또는 speech discrimination score(SDS)에서 $10 \%$ 이상의 호전을 성공으로 정의 하였고 Haynes 등 ${ }^{28)}$ 은 $20 \mathrm{~dB}$ 이상의 pure tone average 호전 이나 $20 \%$ 이상의 SDS 호전을 성공이라 보았다. 이와 같이 각 각의 청력호전 평가 기준은 다르며, 같은 값의 변화라 할지라 도 평가 기준에 따라 청력회복의 성공 여부가 달라질 수 있
다. 본 연구에서는 두 군에서 치료 후와 전의 순음청력역치값 을 뺀 청력역치호전도와 달리 Siegel's criteria에 따른 기준에 는 통계적으로 유의한 차이가 발생하였으며 만일 다른 청력 호전 기준을 적용할 시에 다른 결과가 도출될 수 있는 가능 성도 존재한다.

다른 연구들에 따르면 3개월 이후의 지연성 청력 호전에 대 한 보고가 있다는 점에서 ${ }^{29)}$ 본 연구는 치료 후 추적관찰 기간 이 1 개월로 다소 짧다는 것이 제한점이 될 수 있지만 관찰 시점 을 언제로 할지에 대해서는 아직 논란이 있는 실정이다. ${ }^{30)}$

본 연구는 현재 돌발성 난청 시 스테로이드 경구 요법의 체 계적인 치료 방법, 용량, 용법이 확립되지 않은 점에서 하나의 지침이 될 수 있으므로 그 의의를 찾을 수 있다. 1군은 2군에 비해 청력회복에 동등하거나 일부 지표에서 우월한 결과를 보이며 특히 완전회복률과 이명이 동반된 돌발성 난청의 경 우 1군이 2군에 비해 청력회복에 더 우월한 결과를 보였다.

스테로이드 전신 투여는 환자의 기존 질병을 악화시킬 수 있다는 단점이 있다. 비출혈, 간기능 장애, 위궤양, 녹내장, 골 다공증의 부작용이 보고된 바 있으며 이에 당뇨, 고혈압, 결핵 환자, 임산부에게서는 사용이 제한된다. ${ }^{7)}$ 본 연구에 따르면 상 기 질환이 동반된 돌발성 난청 환자에게 전신적 스테로이드 투여를 고려해야 할 때, 총 투여량은 감소하더라도 1회 투여 용량을 고농도로 하는 것이 더 좋은 결과를 얻을 것을 예상 된다. 전신적 스테로이드의 투여 용법은 돌발성 난청의 치료 에 있어 중요하게 고려해야 할 인자로 보다 정확한 분석을 위 해 더 많은 증례와 장기간의 추적관찰기간, 다기관에서의 공 동연구와 함께 다양한 투여 용법의 효과를 비교하는 전향적 연구가 필요할 것으로 생각된다.

\section{REFERENCES}

1) Whitaker S. Idiopathic sudden hearing loss. Am J Otol 1980;1(3): 180-3.

2) De Kleyn A. Sudden complete or partial loss of function of the octarus-system in apparently normal person. Acta Otolaryngol 1944; 32:407-29.

3) Simmons FB. Theory of membrane breaks in sudden hearing loss. Arch Otolaryngol 1968;88(1):41-8.

4) Jaffe BF. Clinical studies in sudden deafness. Adv Otorhinolaryngol 1973;20:221-8.

5) García Berrocal JR, Ramírez-Camacho R. Immune response and immunopathology of the inner ear: an update. J Laryngol Otol 2000; 114(2):101-7.

6) Westerlaken BO, de Kleine E, van der Laan B, Albers F. The treatment of idiopathic sudden sensorineural hearing loss using pulse therapy: a prospective, randomized, double-blind clinical trial. Laryngoscope 2007;117(4):684-90.

7) Kakehata S, Sasaki A, Oji K, Futai K, Ota S, Makinae K, et al. Comparison of intratympanic and intravenous dexamethasone treatment on sudden sensorineural hearing loss with diabetes. Otol Neurotol 2006;27(5):604-8.

8) Kim Y, Aoyagi M, Yokota M, Fuse T, Suzuki T, koike Y. Effect of 
high dose steroids in idiopathic sudden deafness. Pract Otol 1991; 51(suppl):50-6.

9) Minoda R, Masuyama K, Habu K, Yumoto E. Initial steroid hormone dose in the treatment of idiopathic sudden deafness. Am J Otol 2000; 21(6):819-25.

10) Ochi K, Mitsui M, Watanabe S, Nakashima H, Ohashi T, Kinoshita $\mathrm{H}$, et al. [The effects of high-dose steroid therapy on sudden deafness]. Nihon Jibiinkoka Gakkai Kaiho 1998;101(11):1311-5.

11) Siegel LG. The treatment of idiopathic sudden sensorineural hearing loss. Otolaryngol Clin North Am 1975;8(2):467-73.

12) Mattox DE, Lyles $C A$. Idiopathic sudden sensorineural hearing loss. Am J Otol 1989;10(3):242-7.

13) Wilson WR, Byl FM, Laird N. The efficacy of steroids in the treatment of idiopathic sudden hearing loss. A double-blind clinical study. Arch Otolaryngol 1980;106(12):772-6.

14) Han CS, Park JR, Kim HB, Ahn JK, Park JH, Kang MK, et al. Comparison of the efficacy of systemic and intratympanic steroid treatment on sudden sensorineural hearing loss with diabetes. Korean J Otorhinolaryngol-Head Neck Surg 2008;51(3):227-33.

15) Trune DR, Kempton JB, Harrison AR, Wobig JL. Glucocorticoid impact on cochlear function and systemic side effects in autoimmune C3. MRL-Faslpr and normal C3H/HeJ mice. Hear Res 2007;226(1-2): 209-17.

16) Trune DR, Kempton JB, Gross ND. Mineralocorticoid receptor mediates glucocorticoid treatment effects in the autoimmune mouse ear. Hear Res 2006;212(1-2):22-32.

17) Stachler RJ, Chandrasekhar SS, Archer SM, Rosenfeld RM, Schwartz SR, Barrs DM, et al. Clinical practice guideline: sudden hearing loss. Otolaryngol Head Neck Surg 2012;146(3 Suppl):S1-35.

18) Berrocal JR, Ramírez-Camacho R. Sudden sensorineural hearing loss: supporting the immunologic theory. Ann Otol Rhinol Laryngol 2002;111(11):989-97.
19) Byl FM Jr. Sudden hearing loss: eight years' experience and suggested prognostic table. Laryngoscope 1984;94(5 Pt 1):647-61.

20) Chang DS, Park SW, Choi JY, Kim AY, Park KY, Cho CS, et al. Estimate hearing recovery rate using statistical analysis of sudden sensorineural hearing loss. Korean J Otorhinolaryngol-Head Neck Surg 2011;54(9):603-9.

21) Sheehy JL. Vasodilator therapy in sensory-neural hearing loss. Trans Am Laryngol Rhinol Otol Soc 1960;1960:570-602.

22) Fetterman BL, Saunders JE, Luxford WM. Prognosis and treatment of sudden sensorineural hearing loss. Am J Otol 1996;17(4):529-36.

23) Cvorović L, Deric D, Probst R, Hegemann S. Prognostic model for predicting hearing recovery in idiopathic sudden sensorineural hearing loss. Otol Neurotol 2008;29(4):464-9.

24) Ben-David J, Luntz M, Magamsa I, Fradis M, Sabo E, Podoshin L. Tinnitus as a prognostic sign in idiopathic sudden sensorineural hearing loss. Int Tinnitus J 2001;7(1):62-4.

25) Chang NC, Ho KY, Kuo WR. Audiometric patterns and prognosis in sudden sensorineural hearing loss in southern Taiwan. Otolaryngol Head Neck Surg 2005;133(6):916-22.

26) Mattox DE, Simmons FB. Natural history of sudden sensorineural hearing loss. Ann Otol Rhinol Laryngol 1977;86(4 Pt 1):463-80.

27) Gianoli GJ, Li JC. Transtympanic steroids for treatment of sudden hearing loss. Otolaryngol Head Neck Surg 2001;125(3):142-6.

28) Haynes DS, O'Malley M, Cohen S, Watford K, Labadie RF. Intratympanic dexamethasone for sudden sensorineural hearing loss after failure of systemic therapy. Laryngoscope 2007;117(1):3-15.

29) Lee DH, Jun BC, Lee JH, Son DH, Yeo SW. Clinical analysis of delayed improvement in sudden sensorineural hearing loss. Korean J Otolaryngol-Head Neck Surg 2006;49(7):695-8.

30) Moon IS, Kim J, Lee SY, Choi HS, Lee WS. How long should the sudden hearing loss patients be followed after early steroid combination therapy? Eur Arch Otorhinolaryngol 2009;266(9):1391-5. 